\title{
MOTYW WOLI BOŻEJ W DZIENNICZKU SW. FAUSTYNY KOWALSKIEJ
}

\begin{abstract}
WSTECP
Miłosierdzie jest jednym z najbardziej kojarzonych przymiotów Bożych, jakie znane są ludziom każdej epoki. Jest ono obecne na kartach Pisma Świętego i w wielowiekowym nauczaniu Kościoła. Szczególne miejsce zostało mu jednak przyznane w wieku XX. Okres ten został naznaczony wyjątkową aktywnością cywilizacji śmierci. Wyraziło się to przez dwie wojny, potem przez złe korzystanie z postępującego ze zwiększoną prędkością rozwoju gospodarczo-technologicznego, czy wreszcie, ze źle rozumianej wolności nastawionej na hedonizm. Jednak do zagubionej i oddalonej od Boga ludzkości Bóg wysłał skromną zakonnicę Faustynę Kowalską. Na polecenie spowiednika spisała ona swe mistyczne doświadczenia spotkań z Jezusem w formie Dzienniczka. To duchowe dzieło stanowiące światowy bestseller, który został przetłumaczony na wiele języków, przypomina ludzkości prawdziwe oblicze Boga, w którym jaśnieje miłosierdzie. Iskra Bożego miłosierdzia rozprzestrzenia się na najdalsze krańce świata. Niesie orędzie ukojenia i zbawienia dla zbolałej i pogrążonej w grzechach ludzkości. Dzienniczek spełnia swoją misję i wskazuje ludziom drogę otwierania się na orędzie miłosierdzia. Kierunek ten został potwierdzony „pieczęcią Kościoła”, wyrażającą
\end{abstract}


się w ustanowieniu Roku Miłosierdzia i wydaniu encykliki Deus caritas est, papieża Benedykta XVI.

W tym samym czasie, gdy w Polsce święta Faustyna spisywała duchowe doświadczenia w Dzienniczku, we Włoszech powstawało, jak dotąd mało znane, wielkie dzieło Służebnicy Bożej Luizy Piccarrety. Włoska mistyczka, żyjąca na przełomie XIX i XX wieku, zwana Małą Córeczką Woli Bożej, spisała w 36 tomach osobiste doświadczenie jakiego doznała od Jezusa i Maryi. Fundamentalnym przesłaniem jej dzieła zatytułowanego Królestwo woli Bożej pośród stworzeńn, jest, niedoceniony na polu duchowym i naukowym, przymiot woli Bożej.

Miłosierdzie i wola są dwoma wielkimi przymiotami Boga. Pierwszy jest doskonale znany ludzkości i objawiony na wiele sposobów. Drugi pozostaje dla wielu wciąż tajemniczy, jednak ze względu na rolę jaką spełnia, jest godny poświęcenia mu większej uwagi. Celem badawczym niniejszego artykułu jest odpowiedź na pytanie: Czy w Dzienniczku św. Faustyny Kowalskiej, obok przypomnienia Bożego miłosierdzia, może być ukryty inny skarb w postaci orędzia o świętej woli Boga? Niniejsza praca jest więc próbą odpowiedzi na postawione pytanie. Zostanie dokonane wskazanie motywu woli Bożej w życiu duchowym Apostołki miłosierdzia. Pozwoli to stwierdzić, na ile wola Boża jest skarbem w jej ocenie i ułatwi podanie bardziej szczegółowych wskazań określających wolę Bożą.

\section{1. ŚWIADOMOŚĆ MOTYWU WOLI BOŻEJ}

Motyw miłosierdzia Bożego jest bez wątpienia myślą przewodnią w Dzienniczku św. Faustyny Kowalskiej. Inspirowana mistycznymi spotkaniami z Jezusem Zakonnica, całą swoja uwagę i modlitwę kierowała na zrozumienie tajemnicy orędzia o Bożym miłosierdziu. Dzięki temu Dzienniczek stał się fundamentalnym źródłem wiedzy potrzebnej człowiekowi do przypomnienia bądź odnalezienia

${ }^{1}$ Pełne tłumaczenie brzmi: Królestwo woli Bożej pośród stworzeń. Księga nieba-Przywołanie stworzenia do porzadku, na swoje miejsce i do celu, do jakiego zostało stworzone przez Boga. 
prawdziwego obrazu miłosiernego Ojca, zawsze gotowego do przebaczania. Choć zapiski św. Faustyny stanowią także ostrzeżenie o istniejącym w świecie grzechu i możliwości wpadnięcia w ręce sprawiedliwego Sędziego ${ }^{2}$, to jednak ukazywanie miłosierdzia Bożego w Dzienniczku treściowo przeważa prezentację sprawiedliwości.

W dziele pozostawionym przez łagiewnicką Zakonnicę kryje się również bogata wiedza na temat woli Bożej. Można stwierdzić, iż świadoma tego była sama autorka Dzienniczka. W jej zapiskach ów motyw pojawia się na wiele sposobów i od strony układu treści wspominany jest zarówno w części początkowej, środkowej, jak i końcowej. Biorąc pod uwagę fakt, iż siostra Faustyna nie posiadała systematycznego przygotowania teologicznego, nie należy spodziewać się w treści Dzienniczka wykładu z zakresu dogmatyki, co raczej prezentacji duchowej relacji Boga i człowieka. Apostołka Bożego miłosierdzia wykazuje ogromne zainteresowanie przymiotem woli Bożej. Szuka jej form objawiania się w każdej okoliczności swego życia. Chce ją wypełnić, bo wie, że nie może podobać się Bogu dusza, która nie chce pełnić Jego świętej woli³

W sercu pokornej zakonnicy znajdują się negatywne w swej formie, jak i pozytywne treści motywujące do jej wypełnienia. Święty Paweł w Liście do Hebrajczyków uwrażliwiał, by nie stawiać oporu Temu, który przemawia do człowieka (por. Hbr 12, 25). Jeszcze dobitniej wyraził to Jezus, kiedy w przypowieści nauczał, iż „sługa, który zna wolę swojego Pana, a nic nie przygotował i nie uczynił zgodnie z Jego wolą, otrzyma wielką chłostę" (Łk 12, 47). Siostra Kowalska miała głębokie przekonanie swego wybrania i jako służebnica Pańska, nie stawiała oporu Temu, który powierzył jej dzieło do spełnienia.

Jak na wielką świętą przystało, wypełnianie woli Bożej w jej życiu nie mogło być motywowane jedynie od strony negatywnej. Byłoby to dramatycznym zredukowaniem wizji Boga i przedstawianiem Go w niekorzystnym świetle. Ten sposób argumentacji znajduje swoje uzasadnienie i zastosowanie w przypadku ludzi małej wiary lub

\footnotetext{
2 por. Dz. 1146.

3 por. Dz. 1244.
} 
odznaczających się ignorancją wobec Boga. Stanowi on jedynie alternatywę, swego rodzaju komponent pomocniczy w sytuacji, gdy człowiek nie chce się nawracać i trwa uparcie w swoim grzechu. Dlatego to nie lęk ani zapowiedź kary są dla Faustyny „motorem napędowym" do poszukiwania i pełnienia woli Bożej. Bóg w Dzienniczku Faustyny to Bóg potężny i niezgłębiony w swoim miłosierdziu. Wielkość Jego miłosierdzia, wielokrotnie porównywana jest do głębi bezdennego oceanu ${ }^{4}$. I o ile ocean, czy też mówiąc dokładniej, jego głębia, w rozumieniu biblijnym, nosi najczęściej zabarwienie negatywne (por. Jon 2, 6; Hi 26, 5; Ps 69, 16), o tyle w Dzienniczku przybiera on znaczenie pozytywne ${ }^{5}$.

Taka postawa rodzi nie tylko w Faustynie głęboką potrzebę podążania za wolą Bożą. Gdy Stary Testament proponuje trudne do zachowania Prawo, jako wyraz woli Bożej, a Nowy Testament ukazuje, nie przez wszystkich rozumiany i akceptowany Krzyż Jezusowy, to bezkres Bożego miłosierdzia, w którym grzesznik może się zanurzyć, staje się atrakcyjna ofertą, wręcz przynaglającą do jego przyjęcia. Dzieje się tak dlatego, iż przestrzeganie Prawa rodzi często, niechęć i wewnętrzny opór, a podjęcie krzyża, w naśladowaniu Mistrza, choćby w najszczytniejszym celu, strach i rezygnację. Zanurzenie się w oceanie Bożego miłosierdzia staje się doskonałym stymulatorem pobudzającym do przejścia przez życie, przez wypełnianie woli Bożej. Teksty Dzienniczka, ukazujące grzesznika zanurzonego w głębi Bożego miłosierdzia, czynią to wezwanie do nawrócenia i przyjęcia Bożej propozycji zbawienia dodatkowo przekonywującym.

\section{ROZUMIENIE I WARTOŚĆ WOLI BOŻEJ}

Wizja miłosiernego Boga otwartego na grzesznika i pragnącego jego zbawienia jest z pewnością fundamentem do integralnego zrozumienia motywu woli Bożej w Dzienniczku św. Faustyny. Zostaje ona zanalizowana w niniejszej pracy, zwłaszcza w ramach formułowania

\footnotetext{
${ }^{4}$ Por. Dz. 513, 654, 826, 1776, 1817.

5 Por. Dz. 177, 343, 411, 605, 654, 826, 1582.
} 
końcowych jej wniosków. Za punkt wyjścia szczegółowych rozważań posłużą jednak inne odniesienia, dzięki którym, świadomość pełnienia woli Bożej stawała się dla Faustyny wręcz zachwytem. Do takich z całą pewnością należą teksty mówiące o wartości woli Bożej i przedstawiające sposób, w jaki Faustyna rozumiała samo to pojęcie. Jest to o tyle istotne, iż zdefiniowanie ,woli Bożej” nie jest zadaniem łatwym i nie jest w pełni wyjaśnionym pojęciem. Trudności w jego rozumieniu pojawiają się zarówno na płaszczyźnie biblijnej, filozoficznej a także dogmatycznej. W niniejszej pracy, nie sposób uwzględnić wszystkich aspektów, dlatego na jej potrzeby, zostanie użyte jedynie biblijne rozumienie owego pojęcia, które jest najbliższe siostrze Faustynie.

Artur Malina twierdzi, iż wola Boża w Starym Testamencie w znaczeniu etymologicznym jest wyrażana przez akty pragnienia i chcenia, gdyż w języku hebrajskim nie ma odpowiedników nowożytnych pojęcia „wola”. Terminologia Nowego Testamentu jest zróżnicowana w tym temacie. Najczęściej jednak występującym, w tej części Biblii, pojęciem określającym wolę Bożą jest rzeczownik ,thelēma” i oznacza on treść postanowienia ${ }^{6}$.

W tym samym tonie wypowiada się Wolfgang Langer. Definiuje on wolę Bożą nie tylko jako chcenie Boga, lecz przede wszystkim jako Jego postanowienie, które się spetnia i uzewnętrznia?. Langer dodaje także, iż w orędziu biblijnym nie mówi się o losie, lecz o woli Boga, która może oznaczać nakaz, wezwanie lub żądanie, do którego człowiek musi się dostosować ${ }^{8}$. Można stwierdzić, iż takie rozumienie woli Bożej nie brzmi zbyt optymistycznie. Jednak

\footnotetext{
6 Por. A. Malina, Wola Boża, w: Nowy Słownik Teologii Biblijnej, red. H. Witczyk, Lublin 2017, s. 957-958.

7 Por. W. Langer, Wola Boża. w: Praktyczny Słownik Biblijny. Opracowanie zbiorowe katolickich i protestanckich teologów pod red. Antona Grabner-Haidera, tłum. T. Mieszkowski, P. Pachciarek, Warszawa 1999, s. 1407.

${ }^{8}$ Por. Tamże.
} 
zarówno A. Malina, jak i W. Langer podkreślają, iż Bóg w swojej woli postępuje zawsze dla dobrej sprawy, jaką jest zbawienie człowieka9 ${ }^{9}$.

Podczas lektury Dzienniczka siostry Faustyny da się zauważyć podobieństwa, jakie występują w stosunku do powyższych sformułowań. Nie ma wątpliwości, iż dla pokornej i rozmodlonej zakonnicy wyobrażenie woli Bożej sprowadzało się najczęściej do rozumienia w niej Bożych pragnień i rozporządzeń. Wyrazem tego może być jedna z notatek, w której można przeczytać: „Wola Boża to są Jego (Boga) różne życzenia. Dusza moja pełni je bez zastrzeżeń, bo takie są Jego boskie pragnienia"10. W innym miejscu, Faustyna dodaje: „Niech się stanie o Boże, ze mną to, coś postanowił, nie ma już nic we mnie mojego"11.

Obie notatki zostały poczynione pod koniec życia siostry Faustyny w latach 1936-37. Wskazówka ta, połączona z uważną lekturą pism mistyczki, pozwala dostrzec, iż rozumienie woli Bożej w życiu siostry Kowalskiej dojrzewało, a jej wypełnianie nie było wolne od niedoskonałości. Zwrócił na to uwagę jeden kapłan, któremu Jezus dał poznanie duszy Faustyny i który objawił jej trzy stopnie pełnienia woli Bożej ${ }^{12}$. Pierwszy jest ten, kiedy dusza pełni wszystko, co jest na zewnątrz zawarte przez nakazy i ustawy. Drugi stopień polega na realizowaniu natchnień wewnętrznych. W trzecim dusza zdaje się na wolę Boga i pozostawia $\mathrm{Mu}$ swobodę rozporządzania sobą, by mógł czynić z nią to, co Mu się podoba. W wyznaniu tym Faustyna dowiaduje się także, iż znajduje się ona obecnie na drugim stopniu, ale nie powinna ustawać w staraniach, by osiągnąć stopień najwyższy ${ }^{13}$.

Rozróżnienie to jest niezwykle ważne, gdyż ukazuje pewien dynamizm w pełnieniu woli Bożej. Obcowanie z wolą Bożą nie jest czymś statycznym, zdobytym raz na zawsze i do końca. Przeciwnie,

9 Por. A. Malina, Wola Boża, w: Nowy Słownik, s. 957-958; W. Langer, Wola Boga, w: Praktyczny Stownik, s. 1407.

${ }_{10}$ Dz. 1004.

${ }^{11}$ Dz. 644.

12 Por. Dz. 444.

13 Por. Tamże. 
objawia się ono w procesie poznawczym. Ponieważ jednak wola Boża jest w pewien sposób tajemnicza, czasem nawet ukryta ${ }^{14}$ na jakiś czas przed poszukującym jej, dlatego ów dynamizm uwzględnia fazę uczenia się poprawnego jej rozpoznawania.

Siostra Faustyna doświadczała Bożych znaków w chwilach przeciwności i zwątpienia ${ }^{15}$. Pokornie znosiła cierpienia fizyczne i duchowe $^{16}$, które z dopustu Bożego stawały się jej udziałem. Fakt ten jest o tyle istotny, iż definiuje wolę Bożą jako objawiającą się nie tylko w pomyślności człowieka, co przede wszystkim w tajemnicy krzyża. Podobnie jak, niezrozumiała dla wielu, wola Boża wypełniła się najdoskonalej w ofierze Chrystusa, tak każde cierpienie, dobrowolnie przyjęte dla chwały Bożej, nabiera nowego znaczenia.

Współczesny człowiek niejednokrotnie prezentuje postawę unikania ofiary i cierpienia. Wydaje się, iż dobroć Boga dostrzega jedynie przez pryzmat pomyślności i realizacji własnej woli. Każde zmaganie się z przeciwnościami losu, niespełnianie się własnych pomysłów na życie wywołuje w nim frustrację, w następstwie której winą obarczony jest Bóg. Jedynie nieliczni ludzie dostrzegają szansę na samodoskonalenie $\mathrm{w}$ procesie podjęcia ofiary z życia. Do takich z pewnością należała Siostra Faustyna. Dorastała ona do pełnienia woli Bożej, aż po całkowitą ofiarę z siebie. Rozumiała bowiem, iż Bóg jest pierwszym cierpiącym za człowieka i zarazem współcierpiącym z nim. Ukrzyżowany Chrystus jest znakiem największej miłości i „dowodem solidarności Boga z cierpiącym człowiekiem”" Takie rozumienie Boga i Jego postanowień, objawiające się w ofierze z siebie dla dobra każdego człowieka doprowadzało siostrę Kowalską do zachwytu wolą Bożą i dobrowolnego przyjmowania cierpienia. Był to także najlepszy sposób na okazanie Stwórcy miłości, w którym cierpienie, jak sama mówiła, zamieniało się wtedy w rozkosz ${ }^{18}$.

\footnotetext{
14 Por. Dz. 23.

15 Por. Dz. 121.

16 Por. Dz. 23.

17 Jan Paweł II, Przekroczyć próg nadziei, red. A. Dobak, Lublin 1995, s. 66.

18 Por. M. Czekański, Święta Faustyna o cierpieniu, Kraków 2000, s. 37-38.
} 
Dojście do takich wyżyn świętości zajmowało nie tylko Faustynie, ale i innym świętym wiele lat. Wymagało to od nich wielkiego poświęcenia, a mimo to stawało się ich udziałem zawsze z woli Bożej. Uprzedniość łaski ma tu swoje zastosowanie. W przypadku świętej z Łagiewnik owa łaska była jej dana w sposób osobowy i szczególnie wyjątkowy. Jak wyznawała to sama Zakonnica, woli Bożej uczyła się w szkole Maryi. To Jej zawdzięczała każdy postęp, a potwierdzeniem tego może być następujący zapis z Dzienniczka: „Od tej pory większe mam nabożeństwo do Matki Bożej. Ona mnie nauczyła wewnętrznie kochać Boga, jak i we wszystkim pełnić Jego świętą wolę"19. Obraz Maryi jako pokornej i wyrozumiałej Nauczycielki znany jest z kart Pisma Świętego. Ewangeliczne słowa z Kany Galilejskiej: zróbcie wszystko cokolwiek powie wam mój Syn (por. J 2, 5) doskonale korespondują z późniejszą lekcją, jakiej Maryja udzieliła Faustynie. Poleciła jej wtedy by usilnie i wiernie spełniała wszystkie Boże życzenia, bo to jest najmilsze Jego świętym oczom. Maryja dodała przy tym, że to zadanie należy przełożyć ponad wszystkie ofiary i całopalenia ${ }^{20}$.

Potwierdza się w tym twierdzeniu definicja woli Bożej rozumiana jako Boże pragnienia. Matka Boża, a za nią Faustyna, wielokrotnie dawały świadectwo, iż wypełnianie ich posiada wartość najwyższą. Można sobie wyobrazić jakie byłyby konsekwencje dla ludzkości, gdyby nie Fiat voluntas Tua, wypowiedziane w dniu Zwiastowania. Dostrzegając tę zależność i wielkie znaczenie, jednego tylko maryjnego Tak, siostra Kowalska daje upust swemu zachwytowi wolą Bożą. Przejawia się on w wyznaniu, iż „wierne poddawanie się zawsze i wszędzie woli Bożej, we wszystkich wypadkach i okolicznościach życia (...) ma większą w Jego oczach wagę, niż długie posty, umartwienia i najsurowsze pokuty" ${ }^{21}$. W innym miejscu duchowych zapisków można również przeczytać: „Niech wszystkie upodobania moje, chociażby najświętsze i najpiękniejsze i najszlachetniejsze, za-

\footnotetext{
19 Dz. 40.

20 Por. Dz. 1244.

${ }^{21}$ Dz. 724.
} 
wsze będą na ostatnim planie, a na pierwszym miejscu Twoja święta wola"22. Ów zachwyt Faustyny wolą Bożą staje się jeszcze bardziej zrozumiały, gdy spojrzy się na teksty Dzienniczka, w których sam Jezus podkreśla nie tylko wartość woli Bożej, ale i korzyści wypływające dla tego, który ją wypełnia. Nie sposób wyliczyć tu wszystkich owoców pełnienia woli Bożej, jednak do najważniejszych, zaliczyć można m.in.: zdobycie morza błogosławieństwa ${ }^{23}$, czy też szczególne upodobanie Trójcy Świętej24.

O wyjątkowych walorach woli Bożej i korzyściach z jej wypełniania, Faustyna pisze naprawdę wiele. Teksty cytowane w niniejszej pracy są jedynie namiastką pozwalającą na stwierdzenie bez cienia wątpliwości, iż w rozumieniu Apostołki miłosierdzia wola Boża jest bezcennym skarbem. Każdy, kto go posiada mądrze przeżywa życie i owocnie postępuje na drodze świętości. Trzeba jednak jasno powiedzieć, iż samo szukanie czy też wierne wypełnianie woli Bożej nie jest szczytem wszelkich możliwości w obcowaniu z Bogiem. Dzienniczek Faustyny przekonuje, iż wola Boża, jest wielkim skarbem do tego stopnia, iż należy wyrzec się wszystkiego, a w szczególności własnej woli, by zjednoczyć się z wolą samego Boga ${ }^{25}$. Dopiero wtedy dochodzi do najwyższego ogołocenia, w którym dokonuje się, prawdziwe życie w woli Bożej. Ów poziom został osiągnięty przez św. Zakonnicę - co w 1936 roku potwierdził jej sam Jezus - ale dodał zarazem, iż niewiele jest takich dusz, które go osiągają ${ }^{26}$.

Stwierdzenie to, w pokornym rozumieniu sprawia, iż radość Faustyny z osiągnięcia tak wysokiego pułapu, może być jeszcze większa. Dlatego wydaje ona swoistego rodzaju okrzyk chwały, kiedy pisze: „O wolo Boża, rozkoszy serca mojego, pokarmie duszy mojej, światłość umysłu mojego, siło wszechmocna woli mojej, bo kiedy jednoczę się z wolą Twoją, Panie, wtenczas moc Twoja działa przeze mnie

\footnotetext{
22 Dz. 957.

23 Dz. 954.

24 Por. Dz. 955.

25 Por. Dz. 462, 582, 1107.

26 Por. Dz. 603.
} 
i zajmuje miejsce słabej woli mojej"27. W innym miejscu Dzienniczka objawia się także jej dojrzałe pojmowanie nauki o woli Bożej, kiedy przyznaje: „Rozumiem teraz dobrze, że najściślej duszę jednoczy z Bogiem to zaparcie się siebie, czyli złączenie woli naszej z wolą Bożąa" 28 .

Tak rozumiany motyw woli Bożej nie jest pojęciem nowym. Choć w tradycyjnym nauczaniu Kościoła dominuje bardziej przeświadczenie o wypetnianiu woli Bożej, niż zjednoczeniu z nią, to zwrot ten znany był wielu świętym różnych epok ${ }^{29}$. Doświadczenie duchowe Faustyny w zakresie rozumienia woli Bożej pozostaje ubogaceniem istniejącego już dorobku w teologii duchowości, choć zapewne jeszcze niszowego w oficjalnym nauczaniu Kościoła.

\section{WOLA BOŻA MUSI SIE PELNIĆ}

Uczenie się i odkrywanie na co dzień wielkiej wartości woli Bożej a także postęp w jej wypełnianiu aż do zjednoczenia, doprowadził Apostołkę miłosierdzia, do głębokiej świadomości, iż wola Boża musi się pełnić i nie są jej w stanie zatrzymać żadne przeciwności (por. Rz 9, 19). Autorka Dzienniczka przekonała się o tym wielokrotnie. Jednym z pierwszych tego znaków był zapewne moment powołania nastoletniej wówczas Heleny Kowalskiej. Stojąc na rozstaju dróg między posłuszeństwem rodzicom, którzy nie wyrażali zgody na wstąpienie do klasztoru, a głębokim doświadczeniem duchowym, które podpowiadało jej coś zupełnie odwrotnego, Faustyna postąpiła zgodnie z wolą Bożą ${ }^{30}$. Kiedy potem nie chciano jej przyjąć do żadnego zakonu, nie zrażała się przeciwnościami, tylko uczyła się w duszy, iż do „Ziemi obiecanej”, Bóg prowadzi czasem, okrężną

27 Dz. 650.

28 Dz. 462.

${ }^{29}$ Do najbardziej znanych należą m.in.: św. Franciszek Salezy, św. Alfons Liguori, św. Katarzyna Sieneńska, św. Teresa od Dzieciątka Jezus, św. Jan od krzyża, czy też Służebnica Boża Luiza Piccarreta.

${ }^{30}$ Por. F. Cegiełka, Siostra Faustyna Kowalska. Szafarka Miłosierdzia Bożego, North Tonawanda N.Y. 1954, s. 15-18. 
drogą i nie należy z niej rezygnować (por. Wj 13, 17-18). Podobnie jak w przypadku Mojżesza i Narodu Izraelskiego, tak również i tu była to jedynie lekcja zaufania i posłuszeństwa woli Bożej, która musi się pełnić, a której człowiek powinien się poddać.

Również w późniejszym życiu klasztornym siostra Faustyna doświadczała trudnych do uwierzenia i niełatwych do zrozumienia sytuacji, w których wola Boża objawiała swoją moc. Doskonale ilustruje to zaplanowana przez przełożoną wspólnoty sióstr w Wilnie wycieczka do Kalwarii, w której Faustyna miała uczestniczyćc ${ }^{31}$. W swoich duchowych zapiskach siostra Kowalska opisuje, iż wydarzenie to nie było zgodne z wolą Jezusa, dlatego sprowadził On nagle ciemne chmury na słoneczne niebo, co spowodowało, iż wyjazd nie doszedł do skutku ${ }^{32}$.

Dla człowieka wierzącego podobne wydarzenie nie powinno być niczym zaskakującym. Zgodnie z nauczaniem Ewangelii to, co zostało zapisane w Pismach dokonuje się w pełni i spełnia się wola Boża zamierzona przez Stwórcę od powstania świata aż do jego końca. Przez to potwierdza się zapowiedź Pana, który obiecywał, że będzie ze swoimi uczniami aż do końca świata (por. J 14, 8). Rozumiała to Apostołka Bożego miłosierdzia, która wielokrotnie powtarzała, iż wola Boża musi się pełnić. W całym duchowym bogactwie orędzia o woli Bożej zawartego w Dzienniczku stwierdzenie to jest najczęściej powtarzane $^{33}$. Nie jest ono związane z formą objawiania się Boga, ile raczej jest formą odpowiedzi na podejrzenia, jakie ludzie na Niego rzucają. Rodzi bowiem pytanie: Jeśli wola Boża musi się pełnić, to czy Bóg nie ogranicza wolności człowieka? Czy Ten, który wszystko widzi i wszystko wie, przeznacza człowieka do określonego planu, nie licząc się z jego zdaniem?!

Jednym z tych, którzy podjęli się wytłumaczenia tej kwestii, był św. Jan Paweł II. Napisał on, iż ,wielu ludzi ma tak niejasne wyobrażenie Boga, że często graniczy to z jakąś religijnością bez Boga, pojmującą wolę Bożą, jako niezmienne i nieuniknione przeznaczenie,

\footnotetext{
31 Por. Dz. 64.

32 Por. Tamże.

33 Por. Dz. 386, 409, 479, 573, 586, 665, 897, 1180, 1262, 1389, 1531.
} 
do którego człowiek winien się jedynie dostosować i biernie mu się poddać" ${ }^{34}$. Ojciec Święty tłumaczy jednak, iż prawdziwy obraz Boga jest inny. Ojciec niebieski, który pierwszy umiłował człowieka, powołał go do życia z Sobą i zaprosił do nieustannego dialogu ${ }^{35}$.

Ducha wolności chrześcijan realizujących wolę Bożą podkreśla również papież Franciszek, kiedy stwierdza, iż Bóg pozwala zrozumieć swoją wolę tym, którzy jej szczerze szukają. Tych natomiast, których Jego wola nie obchodzi, do niczego nie zmusza, ale na nich cierpliwie czeka ${ }^{36}$.

Owo czekanie należy jednak dobrze rozumieć. Słowo Boże przedstawia Boga jako miłosiernego Ojca codziennie wyczekującego swego marnotrawnego syna. Kiedy ten wraca uniżony, ojciec wybiega mu na spotkanie, rzuca mu się na szyję i całuje go stęskniony. Potem przywdziewa go w najlepszy płaszcz, zakłada pierścień na rękę i sandały na nogi. Na koniec urządza dla niego wystawne przyjęcie (por. Łk 15, 20-23). Historia ta, jak i podobne przykłady z Ewangelii świadczą, że Bóg nie zmusza człowieka do niczego. Pozwala mu nawet odejść do odległej krainy (por. Łk 15, 13). W tym czasie Bóg nie pozostaje jednak biernym obserwatorem. Jego stan nie oznacza jakiejś stagnacji, czy co gorsze, rezygnacji z człowieka. Wola Boża musi się pełnić, bo miłosierdzie Boże jest nie do zatrzymania. Będzie ono wyglądało człowieka, poszukiwało go (por. Łk 15, 1-7), by wreszcie za cenę jego powrotu, oddać życie na krzyżu.

Apostołka Bożego miłosierdzia doskonale znała ewangeliczne opisy postępowania Boga Ojca w których objawiała się Jego czułość i dobroć. To powodowało, iż motyw woli Bożej i jej nieustawalność wiązała $\mathrm{z}$ bezgraniczną miłością Boga. W tym duchu rozumiała wolę Bożą w stosunku do każdego człowieka, zwłaszcza do biednego grzesznika. Kluczem jest zawsze miłość, jej bezdenna głębia, gdyż jak sama pisała „wola Boża jest miłością i miłosierdziem samym”37.

\footnotetext{
34 PDV 37.

35 Tamże.

36 Por. Franciszek, Ojcze nasz, tłum. M. Dobosz, Kraków 2018, s. 69.

37 Dz. 1264.
} 
Powyższe argumenty, choć tak bliskie siostrze Kowalskiej, dla wielu współczesnych ludzi wydają się nadal niewystarczające. Szybciej im zapewne do oskarżeń Boga, których w historii było wiele. Według tych oskarżeń Bóg jest zły, nie interesuje się człowiekiem i jego losem i postępuje z nim jak z marionetką. Te i tym podobne koncepcje są nie do przyjęcia w rozumieniu chrześcijańskiej woli Bożej. Faustyna wpisuje się w nurt obrońców Boga. Doskonale rozumie, że Bóg wie lepiej, co dla człowieka jest dobre. Jest głęboko przekonana, iż odwieczne postanowienia Boże nie mogą człowieka zawieść, gdyż Bóg będąc samą miłością, nie może nikogo krzywdzić. Nie może On również odstąpić od swoich postanowień (por. 2 Tym 2,13). Widać to szczególnie dobrze w sytuacji, gdy człowiek sprzeniewierzy się przez grzech. Bóg nie cofa wtedy swej łaski a Jego miłosierdzie nie tylko nie ustaje, ale ukazuje się ze wzmożoną mocą ${ }^{38}$. Gdy człowiek wykaże choć odrobinę swej woli, jak dodaje siostra Kowalska, wtedy ani jego błędy, ani upadki, nie są w stanie zatrzymać Boga śpieszącego ze swoją pomocą ${ }^{39}$.

Biorąc Boga w obronę apostołka Bożego miłosierdzia pisze, o pewnym dostosowaniu się Boga do człowieka, do odrobiny jego dobrej woli. Nie może tu być więc mowy o jakimkolwiek naruszeniu ludzkiej wolności. Z drugiej jednak strony, nie oznacza to ani bierności Boga w sytuacji odrzucenia woli Bożej przez człowieka, ani też pierwszeństwa działania człowieka. Należy przyjąć, iż siostra Faustyna, zgodnie z nauczaniem Kościoła, dostrzega uprzedniość łaski i nieustający dynamizm woli Bożej. Potwierdza to między innymi także wtedy, gdy pisze, że choć Bóg chce ludzkiej zgody na Jego wolę, to nie cofnie swej łaski, ani nie umniejszy swej hojności, gdy człowiek odrzuca Boże natchnienia ${ }^{40}$.

38 Por. Siostry Zgromadzenia Matki Bożej Miłosierdzia. Ufność w praktyce życia, Kraków 2003, s. 9.

39 Por. Dz. 291.

40 Por. Dz. 136. 


$$
* * *
$$

Można bez wątpienia stwierdzić, iż w Dzienniczku św. Faustyny, obok orędzia miłosierdzia Bożego znajduje się wymowny przekaz o woli Bożej. Siostra Kowalska rozumie wolę Bożą jako pragnienia i rozporządzenia, których źródłem jest Boże miłosierdzie. Jest ono tak wielkie, iż czyni wolę Bożą nieustannie działającą na rzecz dobra człowieka, jakim jest zbawienie. Orędzie to jest przyczyną swego rodzaju zachwytu dla Faustyny do tego stopnia, iż wola Boża staje się celem jej istnienia ${ }^{41}$. Skłania ją ona do nieustannego i wytrwałego szukania na wzór ewangelicznego poszukiwacza pereł. Gdy znalazł on jedną perłę poszedł, sprzedał wszystko co miał i kupił ją (por. Mt.13 45-46). W zachwycie owym skarbem Faustyna poddaje się woli Bożej na wszystkich jej etapach. Efektem końcowym staje się zjednoczenie z wolą Boga stanowiące najwyższą możliwą łączność z Bogiem.

Należy dostrzec, iż świadomość woli Bożej w życiu Apostołki Bożego miłosierdzia jest na bardzo wysokim poziomie. Jest to spowodowane nie tyle lekturą podręczników teologicznych, ile owocem mistycznego doświadczenia obcowania z Maryją i Jezusem. Niektórzy teologowie twierdzą jednak, że wola Boża jest niezmienna ${ }^{42}$, dokonuje się w jednym akcie ${ }^{43}$ i według nich, o herezję wręcz zakrawa przypisywanie Bogu pragnień lub odczuć. Z drugiej jednak strony, błędem teologicznym, wydaje się postrzeganie Boga i Jego świętej woli w oderwaniu od „czynnika ludzkiego”. Bóg w Chrystusie stał się bowiem człowiekiem. Jego podobieństwo do człowieka we wszystkim oprócz grzechu (por. Hbr 4, 15) uczyniło Go bliższym

${ }^{41}$ Por. L. Grygiel, Zawierzyć Bożemu Miłosierdziu. Mistyka Siostry Faustyny, Kraków 2000, s. 87.

${ }^{42}$ Por. T. C. Donlan, Will of God, w: New Catholic Encyclopedia, Washington D.C.: The Catholic University of America 1967, Vol. XIV s. 915; Jan Szczurek, Trójjedyny. Traktat o Bogu w Trójcy Świętej Jedynym, Kraków: Wydawnictwo Naukowe Papieskiej Akademii Teologicznej 1999, s. 249.

${ }^{43}$ Por. Tamże. 
ludzkości, i w dobrze rozumianej teodycei, Bóg reagujący na sposób ludzki znajdzie swe miejsce.

Tych zaś, którzy takiego rozumienia i pojmowania Boga, boją się przyjąć, można odesłać do Pisma Świętego, w którym licznie występujące antropomorfizmy nie są przeszkodą, ale raczej pomocą w głębszym rozumieniu istoty Boga. Teologowie winni rozważać wolę Bożą objawiającą się nie tylko w podręcznikach innych autorów, ale także na sposób Bogu tylko znany, który przejawia się w mistycznym doświadczeniu świętych.

\section{Streszczenie}

Wola Boża jest rzadziej przywoływanym przymiotem Bożym niż miłosierdzie. Motyw woli Bożej znalazł jednak swoje miejsce w duchowych zapiskach św. Faustyny Kowalskiej. W Dzienniczku zostało zawarte głębokie bogactwo treści poruszające to teologiczne zagadnienie. Okazuje się, iż siostra Kowalska, nie tylko przekazała orędzie o Bożym miłosierdziu, ale była głęboko zafascynowana wolą Boga. Od najmłodszych lat szukała jej i wiernie ją wypełniała.

Dzień po dniu odkrywała jak wielką ma ona wartość i jak koniecznym jest jej poznawanie. Pod okiem Maryi i Jezusa Faustyna przechodziła wszystkie etapy uczenia się woli Bożej, aż do całkowitego zjednoczenia się z nią. Wypełnianie pragnień i postanowień Bożych, bo tak rozumiała ona to pojęcie, stało się dla niej celem jej istnienia. Święta z Łagiewnik pojmowała wolę Bożą jako skarb, który został dany ludzkości z powodu wielkiego Bożego miłosierdzia. Apostołka Bożego miłosierdzia odkrywała, że wola Boża musi się pełnić, gdyż Bóg nie może przestać kochać.

Slowa kluczowe: Faustyna Kowalska, wola Boża, miłosierdzie, Jezus Chrystus, Maryja, Dzienniczek, Luiza Piccarreta

\section{Summary}

The will of God is the less-discussed attribute of God than His mercy. The theme of God's will, however, has found its place in the spiritual notes of Saint Faustina Kowalska. In Diary there is a profound richness of content, characterizing this theological concept. It turns out, that Sister Kowalska, not only promoted the 
message of God's mercy but was deeply fascinated by the will of God. She was looking for it and faithfully fulfilled it from an early age.

Day after day, she was discovering of how great its value was, and how necessary it is to get to know it. Under the guidance of Mary and Jesus, Faustina, has gone through all the stages of learning God's will, until she was completely united with it. The fulfillment of God's desires and decisions - she understood this concept this way - became the goal of her existence. The saint of Lagiewniki understood the will of God as a treasure, that was given to mankind because of great God's mercy. The apostle of God's mercy was revealing that the will of God must be fulfilled because God cannot stop loving people.

Keywords: Faustina Kowalska, God's will, mercy, Jesus Christ, Mary, Diary, Luiza Piccarreta

\section{Biogram}

Ks. Wojciech Komosa, ur. 25.10.1979 r. w Opolu. Od 2004 roku jest kapłanem archidiecezji lubelskiej. W tymże roku uzyskał tytuł magistra teologii na Katolickim Uniwersytecie Lubelskim. W 2018 uzyskał stopień licencjata teologii w zakresie teologii moralnej. Obecnie kontynuuje studia doktoranckie w Katolickim Uniwersytecie Lubelskim Jana Pawła II w Lublinie. Jego szczególnym zainteresowaniem na polu naukowym jest szeroko rozumiane pojęcie woli Bożej. Mieszka i posługuje jako spowiednik i kierownik duchowy w parafii Matki Kościoła w Świdniku.

\section{Bibliografia}

Cegiełka F., Siostra Faustyna Kowalska. Szafarka Miłosierdzia Bożego, North Tonawanda N.Y.: Pallottinum 1954.

Czekański M., Święta Faustyna o cierpieniu, Kraków: Wydawnictwo M 2000.

Donlan T.C., Will of God, w: New Catholic Encyclopedia. Washington D. C.:

The Catholic University of America 1967 Vol. XIV, s. 915.

Franciszek, Ojcze nasz, tłum. M. Dobosz, Kraków: Wyd. Znak 2018.

Grygiel L., Zawierzyć Bożemu Miłosierdziu. Mistyka Siostry Faustyny, Kraków: Wyd. Znak 2000.

Jan Paweł II, Adhortacja apostolska Pastores dabo vobis, Watykan (25.03.1992).

Jan Paweł II, Przekroczyć próg nadziei, red. A. Dobak, Lublin: Redakcja Wydawnictw KUL 1995. 
Langer W., Wola Boża, w: Praktyczny Stownik Biblijny. Opracowanie zbiorowe katolickich i protestanckich teologów pod red. Antona Grabner-Haidera, tłum. T. Mieszkowski, P. Pachciarek, Warszawa: Instytut Wydawniczy Pax 1999, s. 1407.

Malina A., Wola Boża, w: Nowy Stownik Teologii Biblijnej, red. H. Witczyk, Lublin: TN KUL 2017, s. 957-958.

Pismo Święte Starego i Nowego Testamentu w przekładzie z języków oryginalnych.

Opracowat zespót biblistów polskich z inicjatywy benedyktynów tynieckich. [tzw. Biblia Tysiąclecia], Poznań: Pallottinum 2002.

Siostry Zgromadzenia Matki Bożej Miłosierdzia, Ufność w praktyce życia, Kraków: Misericordia 2003.

Szczurek J., Trójjedyny. Traktat o Bogu w Trójcy Świętej Jedynym, Kraków: Wydawnictwo Naukowe Papieskiej Akademii Teologicznej 1999.

Św. Siostra Faustyna Kowalska, Dzienniczek. Miłosierdzie Boże w duszy mojej, Kraków: Misericordia 2008. 